\title{
The Effect of National and International Culture on Logo Design of Iran's Graphic Art
}

\author{
Maryam Monirifar \\ Hacettepe University, Turkey \\ maryam_monirifar@yahoo.com
}

\begin{abstract}
Art is an intellectual accumulation, which is unique to the society where it exists, and it is shaped by that land's culture. In the other words, art is not an element, which can be taken from other cultures directly and applied to a society. On the other hand, communication instruments play a significant role in transferring the cultural and artistic heritage, which are the basis of a country. Furthermore, graphic design is a language which conveys a message, it is an identification of the cultures and it is unique to the countries. However there are several factors that influence the graphic design of a country such as historiy of the country, believes, political structures and cultures.

This study aims to focus particularly on Iran's ancient and rich culture, Its principles of graphic arts, and development of it in this cultural at different periods such as when the culture was under the influence of religion In addition, the social and cultural factors which affect the graphic design were studied with theiradvantages and disadvantages. In conclusion, the historical process of Iranian graphic art throughout history was studied by taking the development of Iranian graphic art into consideration with respect to socio-cultural perspective.
\end{abstract}

Keywords: İran, Graphic art, Cultural, History. 


\section{Introduction}

Human beings started graphic arts from the moment they decided to convey a visual message of a certain concepts. Despite all of the improvements and changes in today's world, graphic design is still on its way in a similar manner. Beginning of graphical art in Iran dates back to old times and this shows the deep and rich culture of the country. Designers created infrastructure of art and the modern graphic with geometric, simple but meaningful and impressive designs inspired from the nature. Graphic design varies from culture to culture and the reason of this is based on the history, religion, culture, beliefs of the people, and life style of the country where it is emerged. Although the impacts of foreigners exist in Iranian graphic art's development, original and unique artefacts were created. In this article, selected examples, which illustrate Iranian rich and ancient culture, are investigated. By studying the principles of graphic art and its development in this local culture, different sociological periods will be invstigated too. In addition, the social and cultural factors which affect the graphic design were also analyzed with their positive and negative aspects.

\section{The Origin of Iranian Graphic Arts}

In the human being's general cultural history, the drawings that were created by primitives in caves are known as the initiation of graphic design. Since ancient times, graphic images have been used for ornamentation of pots, vases and other items. This art is obviously seen in ancient civilizations such as Iran. In ancient Iranian civilization abstract embroideries and motifs were popular and consisted of combinations of letters and paintings and usage of seals which inferred the initiation of logos and signs use.

Archaeologists have determined that the Iranian civilization goes back to eight hundred thousand years ago. The first paintings found in caves in Iran are thought to have been made in a cave named Yafteh in the Zagros Mountains from 40 thousand years ago. In addition, although 
the paintings found in a cave named Doushe in Mirmelas range had been made in $12^{\text {th }}-8^{\text {th }}$ centuries B.C, which are very valuable and famous. In Iranian civilization, there has been also pots which are made up from clay together with wall scrapings, seals, coins, inscriptions and sculptures. The most famous one of these pots had been found in Tepe Sialk and Susa. In these artefacts, relief embroidery is seen as well and they belong to 4-6 thousand years ago. The figures which had been used were drawn in very simple and geometric forms of animals and nature. Illustration of letters in paintings of that times and the figures in the founded artefacts are also seen as the origin of calligraphy, and the significant relation between calligraphy and painting can be determined in many designs.

The advantages of the metal over clay such as durablity and toughness, and the development of metal molding methods have made a major impact on human civilization. The most famous examples of bronze which are found in Iran belong to Lorestan and are statues representing human beliefs. Apart from that, the artefacts which have forms of reliefs or sculptures and are staged on gold have been found in Marlik and are ranked as one of the most beautiful artefacts world wide.

Centuries ago, because graphic art had elements in common with calligraphy and painting, it was generally preferred in books illustrations. Also writings and texts had an effective role on conveying a message as being one of the graphic factors. In the Iranian civilization, many examples of inscriptions can be found such as Ashurbanipal inscriptions, Dairush's dual inscriptions, Bisutun inscription, the inscriptions in Shapur Cave and Achaemenid inscriptions. Some of these inscriptions have been combined with visuals by telling a story like Bisutun and have created a really successful illustration (Picture 1). 


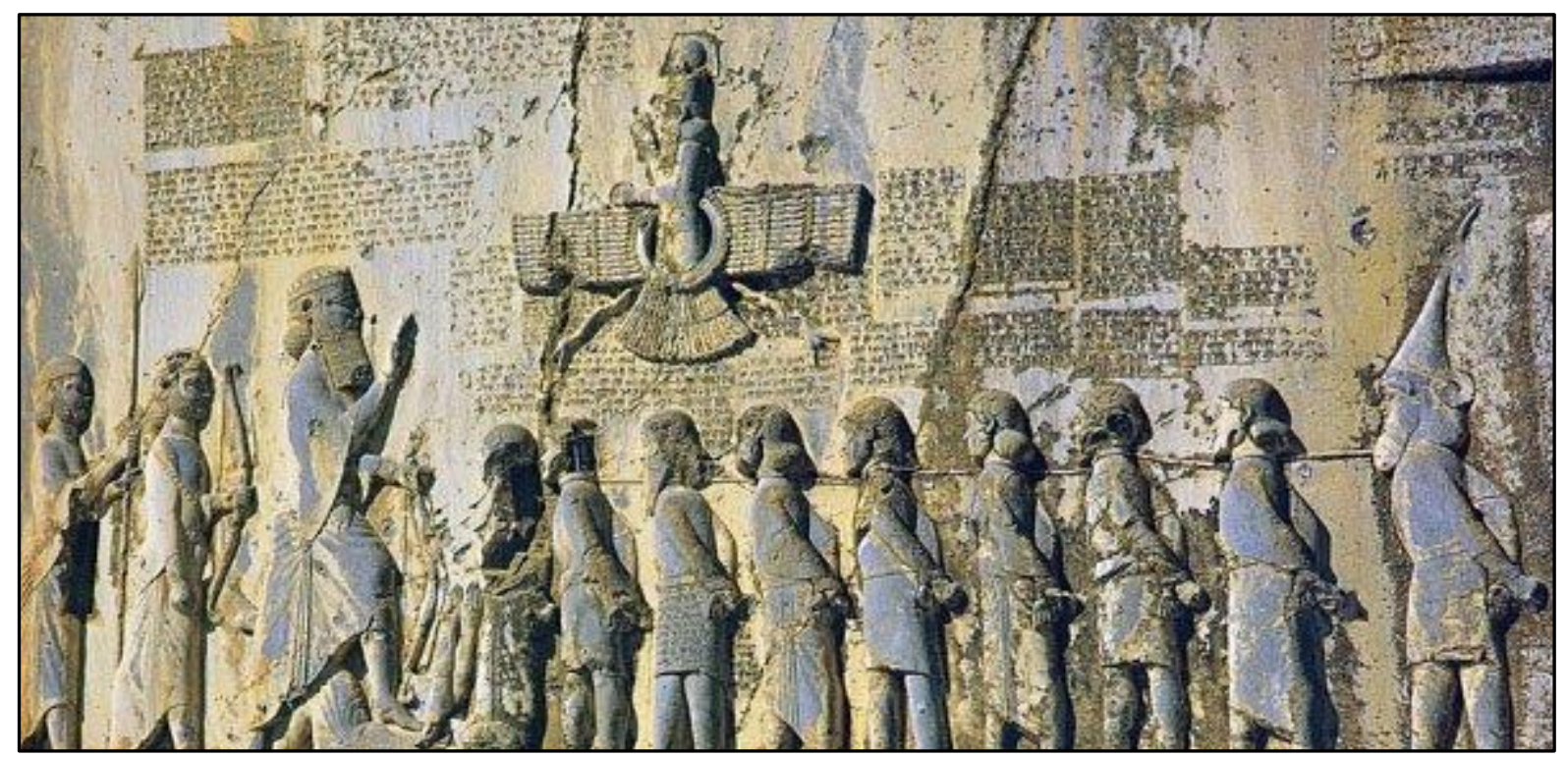

The picture 1: Bisutun's Inscription and Relief Embroidery. Bisutun Inscription has been created in Bisutun Mountain as the biggest inscription in the world and has been one of the most famous, and one of the most important artefacts of Achaemenid Dynasty. This inscription and relief embroidery describes the Great Dairush's victory against Magus Gaumata and the rebels’ are being shackled.

Advertising which is the most significant aspect of communication is one of the other subjects which can be discussed in graphic design. Genraly the starting date of graphic is assumed as the date it began with advertisements. Sultans have tried to build cemeteries and inscriptions for recording the memories in the next generations' minds and the desire of being remembered. The best examples of this are Pasargard which was built in the period of Achaemeneid, Naqshe Rustam, and Takht-e Jamshid that each of these structures are an icon in Iranian history. More than three thousand relief embroideries are found in Takht-e Jamshid, and they were all built with an incredible harmony. Some of these embroideries can be named as follow: Dariushe Achaemenid, symbol of Faravahar, gifts brought to Sultan, soldiers standing in line and legendary animals. These are proofs of this period's magnificence, and banquets which had been held in this period. 
In Iranian civilization, different aspects of art progressed in different periods, and the founded seals, coins, paintings, pots, ceramics, metal artefacts, sculptures, wall scrapings, calligraphies, illuminations and book adornments are the evidences of this civilization's rich art. Indeed an artistic or cultural piece belongs to the land that it has been created in. That is why the artistic pieces should be returned to where they belong.

\section{Properties Of Iranian Culture}

Art is a cultural accumulation which is unique to the society it belongs to, and it is formed by that society's culture. That's why it can not be an element which is taken from elsewhere. On the other hand, communication plays a significant role in transferring the cultural and artistic accumulations which rely on the traditions of each country. Thus, the cultural and artistic characteristics of each country is affectd by others and brings the opportunity to develop and distribute what is called "art". Since graphic design is a language which conveys a message, it plays the role of identification at the same time. These being said, we manage to understand that countries' histories, beliefs, political structures and cultures play a key role.

The significance of Iranian art and its exclusive cultural features are well-known. Iranian art's boundaries are both historically and geographically wide to the extent that researchers have examined Iran's artistic change in the light of cultural features in order to reach a coherent result. The features of Iranian culture which has left an undeniable influence on Iranian art can be summarized as follows:

- Iranian cultural features are not limited to the land's geograpgical and political boundaries.

- Ancient Iranian population was composed of individuals with various nationalities. This diversity is reflected as a myriad of artistic methods in a vast geography.

- Generally, the development of branches of art came true by Sultans' supports and their taste had affected practices of art. Thus, changes in Iran' monarchic dynasty, variant 
political history and people who supported the art, had been very effective in the creation of art.

- Since the country of Iran is located between Europe and Asia, it is deemed as the unifying bridge between "east', and "west', On account of this special geographical position, Iranians formed an integrated culture and selected and used some of the properties of other cultures, so they were able to create an original culture and eventually left their footprint on the world culture.

- The point which makes Iranian art exclusive is its original source which is fed by its pure and absolute culture. The feature that makes the Iran and the Iranians special and distinguished from other nationalities is the social and cultural union between them (Pirhushyar, Marasi, 2012).

The elements which interconnect Iranians and allow the initiation of a common nature of "Iranian" are the Persian language, Islam, and Islam's cultural region. Although throughout history, the land's borders had changed and various governments had taken the lead on it, it has accomplished to subsist as a cultural region. Iranian art has generated the most important part of the cultur in this region. The Iranian culture, except for its art, had affected most countries' arts from "east" to "west". The art works, which are similar to Iranian art, can be found in different countries and are the proofs of this fact. In ancient times, Iran's art had covered a very vast geography with the paintings, clays, seals, coins, ceramics, wall scrapings and illuminations in the caves. However, Iran's graphic art's origin should be searched in calligraphies and paintings.

\section{Before The Islamic Period}

Carvings in caves, sculptures, seals, inscriptions, coins, ceramics and pictures on them are the oldest and the most splendid examples of graphical art in Iranian civilization. Achaemenid Kingdom (550-330 B.C.) known as one of the greatest empires in the world has been known as 
one of the most important eras before Islam for the development of art. In this period, architectural peak was reached; invaluable pieces were completed in Takht-e Jamshid, Pasargad and Shush. Domination of Achaemenid Kingdom over surrounding countries resulted in affecting different cultures; however, despite of this, Iran preserved its culture and this reflected in artworks. That's why Achaemenid Kingdom managed to create precious artworks by using the Iranian art's significant features. The coins, seals, bronze and golden pieces, sculptures, inscriptions and especially wall scrapings which are from that period are valuable and exclusive. Embroideries shaped with the combination of eagle, lion, horse and other animals like them can be seen frequently on sculpts in Achaemenid and especially in Takht-e Jamshid (Picture 2). These shapes are considered as symbolic and mythic icons by some. Sculpts and relieves in this period emphasize the symmetric harmony, glory and magnitude.

As the Sassanid Empire (224-651 A.D.) thought themselves as the cultural heirs of Achaemenid, they tried to revive their art style. Many priceless artworks that belong to this period such as sculpts, silver pieces, mosaics, pictures and wall inscriptions have been explored. Wall Inscriptions of theSassanid Period have the characteristic of Achaemenid artworks, however, despite of all of the similarities, what separates and makes Sassanid wall inscriptions special, is their choice of moving and fictional objects. In the pictures of this period, various plant and animal motifs, which bear symbolic meanings, were used. Besides this, use of miniatures brought the basis for a new style. In this period, a prophet and artist named Mani arised against Zoroastrianism and showed his miracle with a painting. He used art to introduce his religion and presented the examples of his paintings in his book named Arzhang. This way, he created a style which was similar to the art works which had been developed in the earlier Islam age. This shows the effect of this period on Islamic art (Picture 3). 


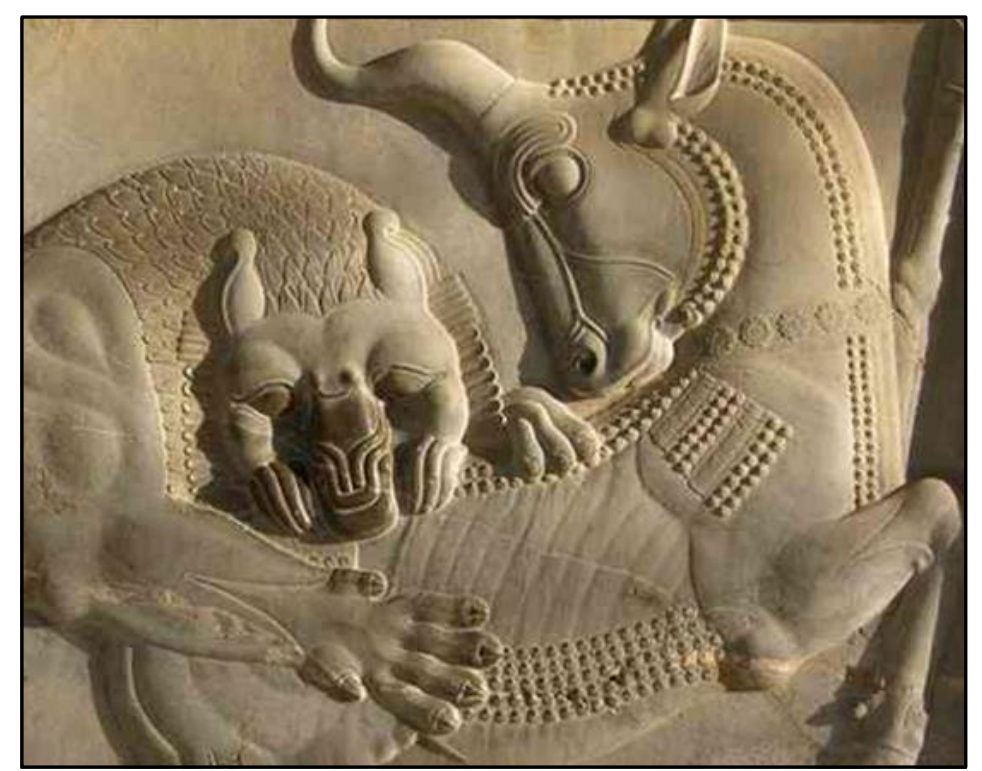

Picture 2: The motif of lion attacking a cow is seen in

Takht-e Jamshid. According to beliefs, the yellow skin of lion, excessive power, mane and hair, sunlight are the signs of power and talent.

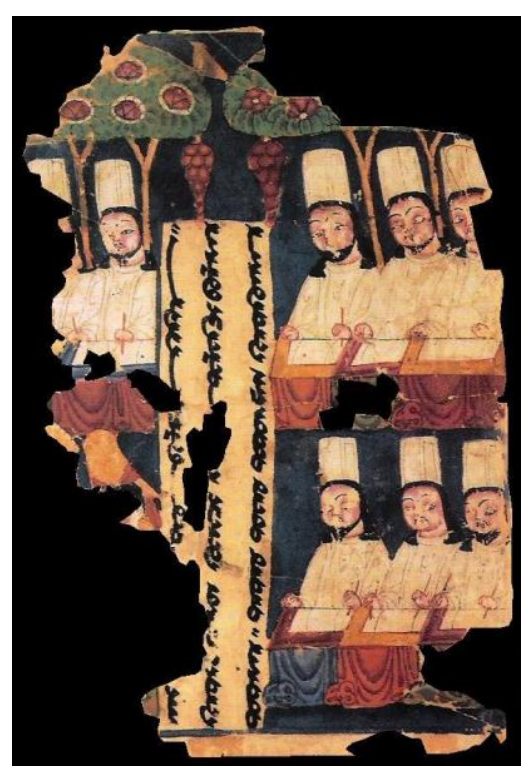

Picture 3: A painting of book named Arzhang of Mani belonging to 8th and 9 th centuries.

Also, peoples beliefs, thoughts and their religious practices are reflected in their works in the period before Islamc age. It seems as if some sculpts were built in order to show respect and this shows the impact of religion on people's life and their art works (Picture 4, 5). 


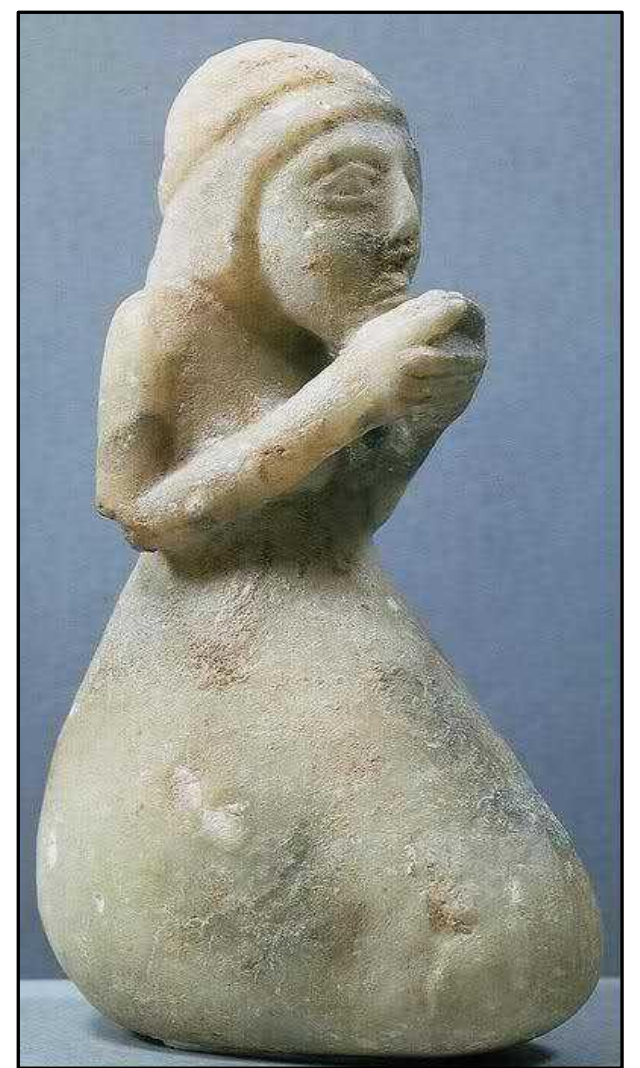

Picture 4: Marble statue of a woman praying,

found in Shush (3300 BC), on display in

Louvre museum

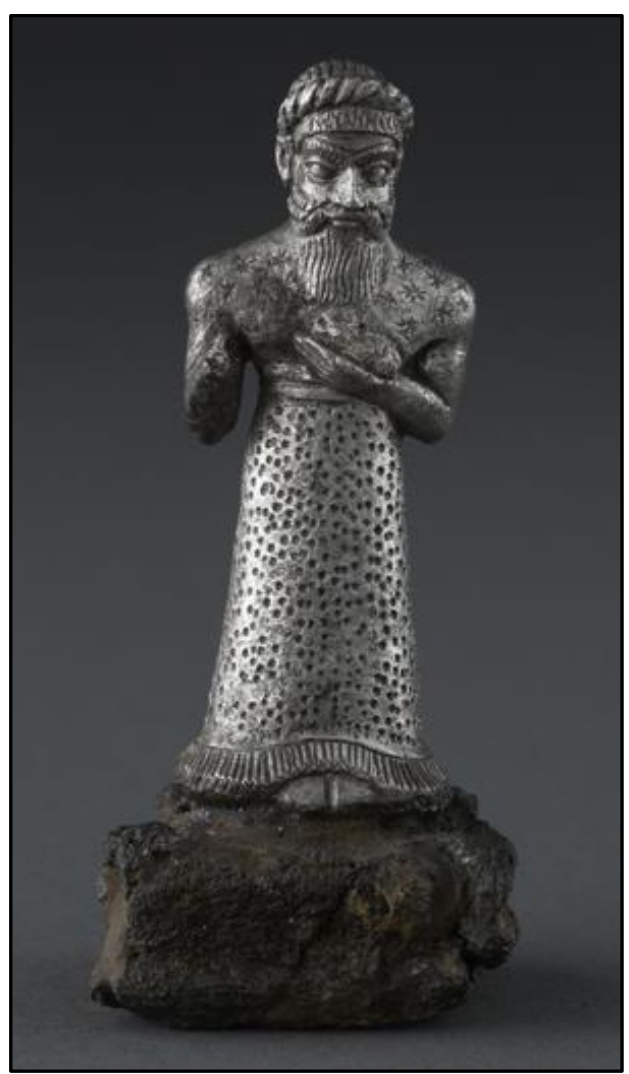

Picture 5: Bronze and silver statue of a man praying, found in Shush (1500-1200 BC), on display in Louvre museum

\section{After The Islamic Period}

In general, art is inspired by rituals and religious ceremonies and people try to explain their emotions and religious beliefs by art. A glance at history reveals that how great and important is the effect of religion on societies and cultures. This influence sometimes goes beyond social life and it affects cultural activity and the progress of art as well. Throughout history, although religion has debilitated a specific style or branch of art in an era, it has contributed to other styles or branches of art. This was applicable to Iran along with other nations. In the countries that were commanded by Islamic rules, sculpture and similar arts was not dignified and appreciated as much as in the countries dominated by Christians and Buddhists. Since paintings and sculptures were sanctified, according to regressive Islamic beliefs they were prohibited. 
That's why the Islam tried to terminate art and sculpture. In Iran, from the first years of domination of Islam to the Seljuk period, there was a high pressure on art. Administrators and reverends in that period hindered the progress of art and imposed a ban on artists on the grounds that illustration is forbidden by Islam. However, they used paintings and especially human figures in their palaces.

Belief is one of the most important factors in art, and art is ranked as the most effective way in expressing sectional feelings. In Islamic period, the relation between art and religion has developed more than ever. Religious books are the best examples of graphical design. Muslims have created a decorative and arabesque design in ornamentation of their buildings and books by means of using human images and benefiting from graphic principles and geometric shapes and lines. In Islamic art, "arabesque" is generally used as a sign of endless nature created by Allah.

Calligraphy, which can be counted as the most distinct Islam art, is accepted as an art language for all of the Muslims. Calligraphy and decorative handwritings are available in many places. Handwriting is used as a decoration in wall instructions, domes, coins, ceramics, canisters, weapons, clothing and textile, manuscripts and in many others like them (Picture 6). Painting was born as miniature after Islamic period and was later used in different styles in famous literary and religious books, illustrations of old Iranian myths and in manuscripts (Picture 7). Since emperors in Safavid period (1501-1722) cared about culture and art, this period is considered as the brightest period of Iranian art. In this period, painting reached its peak in Islamic artworks and then in Zand and Qajar periods, different styles were introduced by use of different perspectives. Pottery and ceramic art were developed in this period as well. Besides decorative designs, artists created novel and invaluable artworks by using calligraphy. 


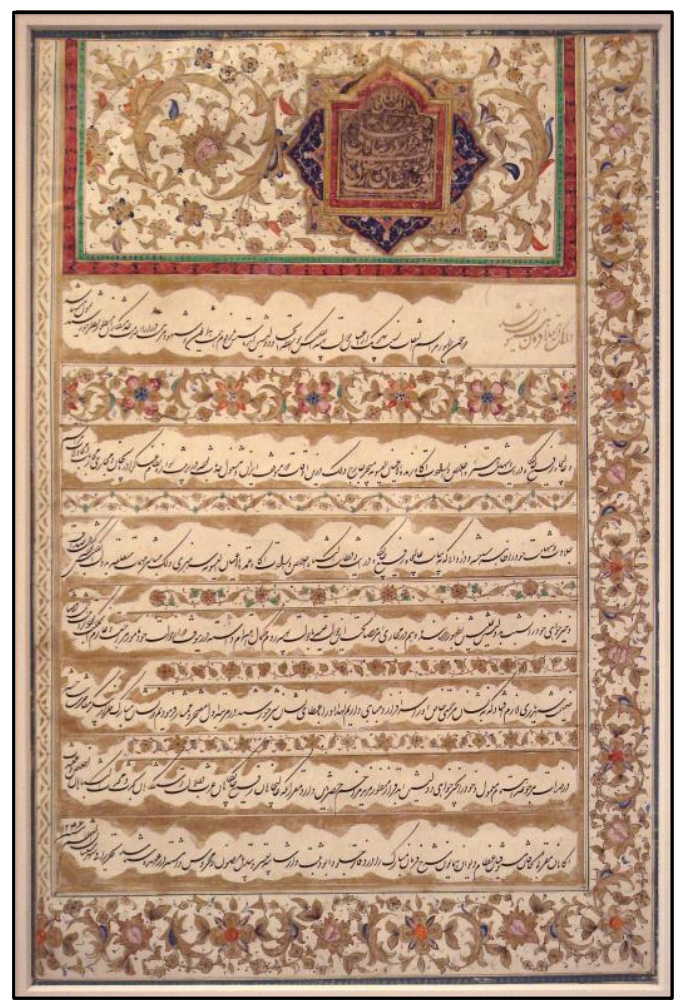

Picture 6: Calligraphy example of Qajar Period

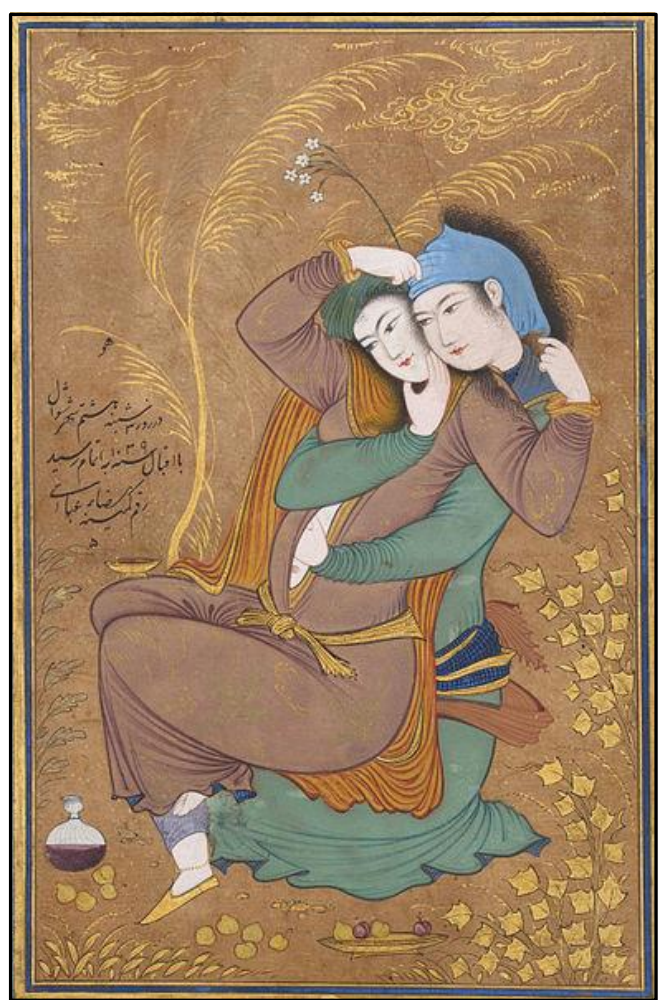

Picture 7: Painting example of Safavid Period

\section{The Origin of Modern Graphic in Iran}

If we think the invention of printing press as the beginning of the World Modern Graphic Art, we can say that modern graphic began in Iran with the establishing of printing press in the Safavid dynasty (A.D. 1501-1722). Although metal printing is more advantageous, it was abolished to be used after a while because of nomurous problems. Press printing was costly, difficult to operate and repair, typesetting and proofreading were not easy and it had limitation in pressing images. Therefore the lithography technique was used instead (1248 AH). On the other hand, several advantages of the lithography method such as: simplicity of the technique, its low price capabality of calligraphic printing, printability of gliding, purfling, artistic decoration and motifs, predominated this method to metal printing. Lithography had been used as a unique printing method for nearly 70 years and it had a crucial effect in development of graphic art (Dabiri, 2005). Similar to anywhere in the world, in Iran the first newspapers were 
printed with the aid of proselytising, later the quality of the prints were improved with the government's help.

Painting is considered as the basis of graphic design, in Iran the first art school was established by Safavids in 1591 called "Painting Factory" (Lunar 1000). Later, in Qajar period the modern art education with the establishment of famous art schools like Dar ul-Funun, Majma ul-Sanaye, Sanaye Mostazrefeh, and other art schools started to educate art enthusiasts. In Qajar period (A.D. 1795-1925), a famous artist Sani-ol-molk (Abol Hasan Khan Ghaffari) who studied art in Italy, played a major role in establishing of Iranian modern art. Sani-ol-molk was the best artist of Qajar period, he is also called as the Iranian Rafello. He learned about lithography while studying in Italy and after turning back to Iran, he prepared the first printed pictures of newspapers of his time with his students by administrating a weekly newspaper. Moreover, he is the first person who used illustration in modern style printings and established Majma ul Sanaye art school.

Even though Iran has long history of graphic art, this art field was also affected by the western art like other cultural factors. Since 1908, the western techniques and methods began to influence the Iranian graphic art. Two Armenian siblings, Musheng and Napoleon Soruri designed the first movie posters in Iran. These posters with huge oil-paintings were designed for the cinemas. Later, a Swedish named Fredrik Talberg designed some other posters. He became the pioneer of improvement of Iranian modern graphic art with several designs such as the logo of the Iranian Railways and the logo of the Sepah Bank (Picture 8,9). 


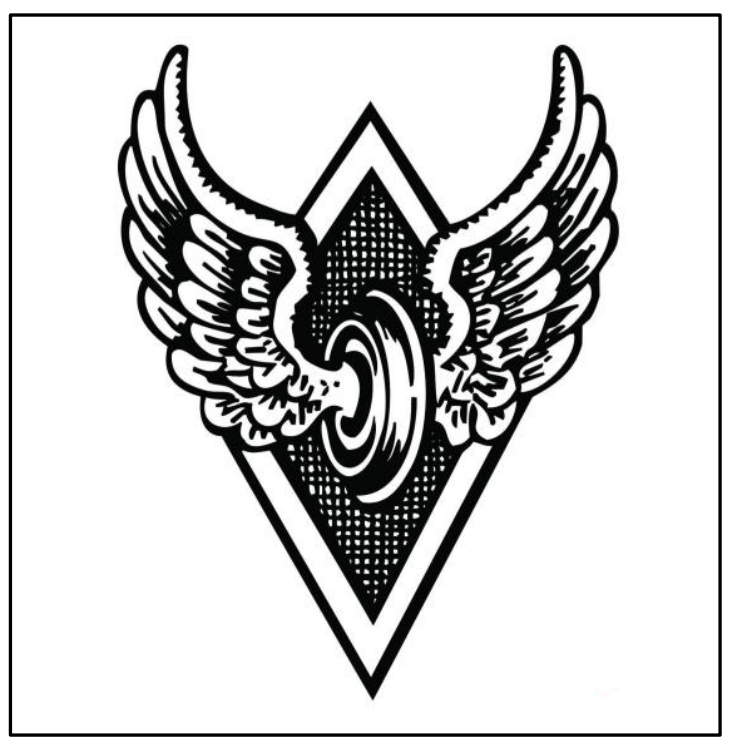

Picture 8: The railway logo of Iran

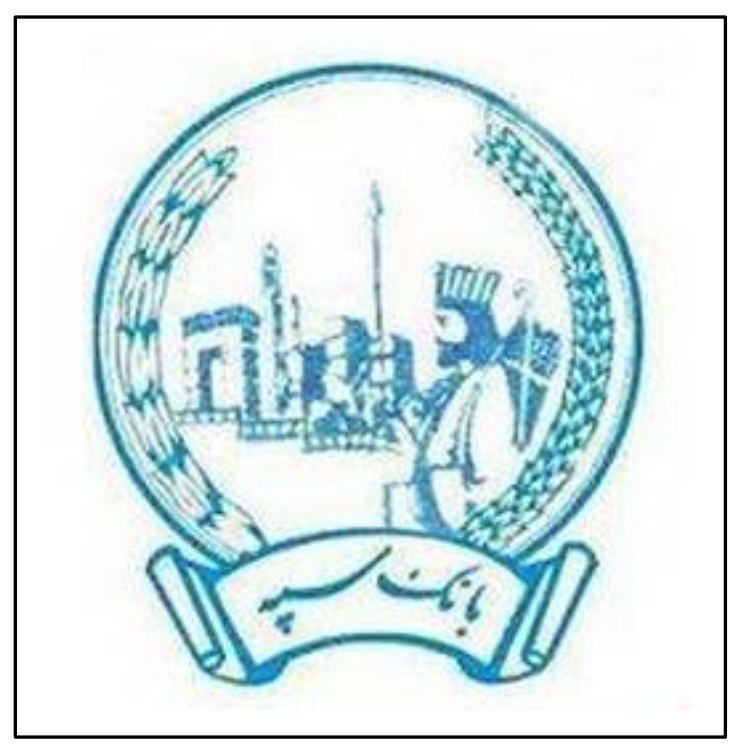

Picture 9: The old logo of Iran sepah bank

Foreigners ruled even the first art schools and art universities in Iran. Besides, the Iranian educated artists who were trained in UK and United States applied the western methods and techniques that they had learned. The first faculty of fine-arts established in Tehran University in 1941 which offered the graphic art and designing courses. Later on, the graduates of this program conducted several graphic arts workshops and started to train the art enthusiasts. The popularity of the graphic design rose with the establishment of other faculties of fine arts. The first graphic design exhibition was held in 1964 at Tehran, At the same time, the first Asia Design Biennial was held in Tehran where the designs of all Asian countries were exhibited there. Unfortunately, because of the tension after Iranian Revolution, the exhibitions suspended. The first Iranian Graphic Design Biennial was also held in Tehran Museum of Contemporary Art in 1988. 


\section{The Periods Which Affected the Iranian Graphic Mostly}

Throughout history in different periods, there has been rises and falls in different branches of Iranian art. Artworks which survived from Achaemenid, Sasanian, Seljuk, Timurid Safavid and Qajar empires are known as the most valuable and most famous artworks in the world. Among these kingdoms, art reached to its peak in the periods of Achaemenid and Sasanian before Islam, and it flourished in the periods of Safavid and Qajar after Islam. Athough the Iranian graphic art dates back to ancient times, it significantly improved in certain periods, which resulted in significant artefacts. Artefacts produced in the period of Sasanian and Achaemenid not only were remarkable in that period but also created infrastructure of the modern graphic arts. The motifs and embroideries which are nurtured from religion, faith and tradition have maintained their unique features throughout the centuries. Excavating these works that host both history and today's cultural and conditions, has led to unveiling of the unknown works of Iranian culture and civilization. Besides, this great treasure presented by Iranian culture has a remarkable importance in strengthening the domestic arts, meeting the needs of today's art community and introducing Iranian art to other countries. Graphic art plays an important role in the relation between the public community and the art world. In today's world graphic art has such a significant influence in the growth and development of society. By analysing graphical art in the ads, effective information can be retrieved to understand the characteristics of the society. Moreover, designers inspired the Iranian noble art and embroidery, and as a result they have reached a new language which is a combination of graphics and native arts. This language has become the identity of Iranian artefacts. In ancient time's human's relation with the nature and his detailed observation of the environment led to formation of various designs depicting humans, plants, animals and geometric designs that each of which has become motifs involving its own culture. Designers were inspired by these beautiful, simple motifs that have deep meanings, and applied them to their artworks especially in logo design. 


\section{Cultural Icons That Are Portrayed In Graphic Designs}

The pieces that are created by Iranian graphic artists are either crafted by having an eye on precious ancient cultural monuments, which can be comprhended by knowledge in graphics, or are inspired from past.

Some of the most famous logo designs inspired by Iran's anecient era are as follow:

\section{The logo of Iranian Airways}

This logo was designed in 1961 by Edward Zahrabi. His design was inspired from the head of a column in Tact-e Jamshid complex which dates back to the Achaemenid period. Zahrabi in aim to use Iranian motifs, chose the Huma, a bird in Iranian legends that only similar of which is seen in Takht-e Jamshid. This mythological animal which is carved at the top of column is a combination of an eagle with horse mane and cow ears. According to some sources, Huma is a fortune bird that never sleeps, flies continuously at high altitudesthroughout his life, and never rests. This is evidence that the designed logo has how much harmony with the Iranians believes, mythological thoughts and cultural structure. Moreover, according to air transportation news agency (skift) in the 2013 report, this logo has been selected as the best logo among the airway companies throughout the world, thanks to its charm, simplicity and clear message (Picture 10, 11). 


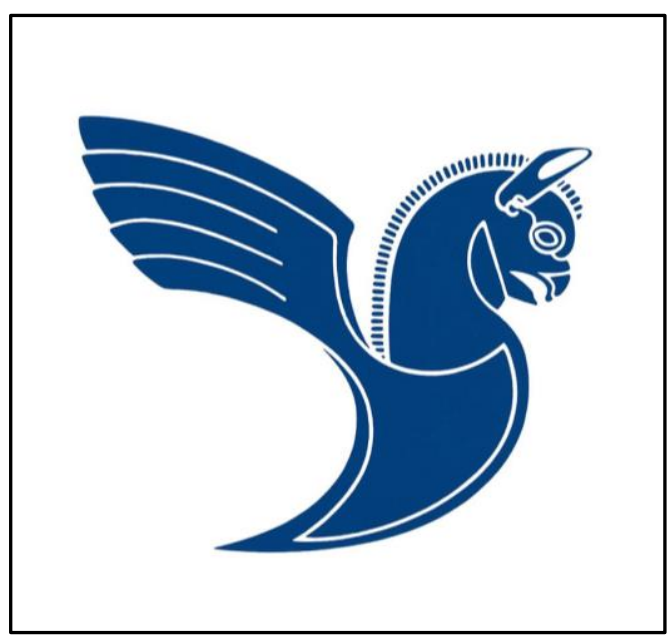

Picture 10: The logo of Iranian Airways

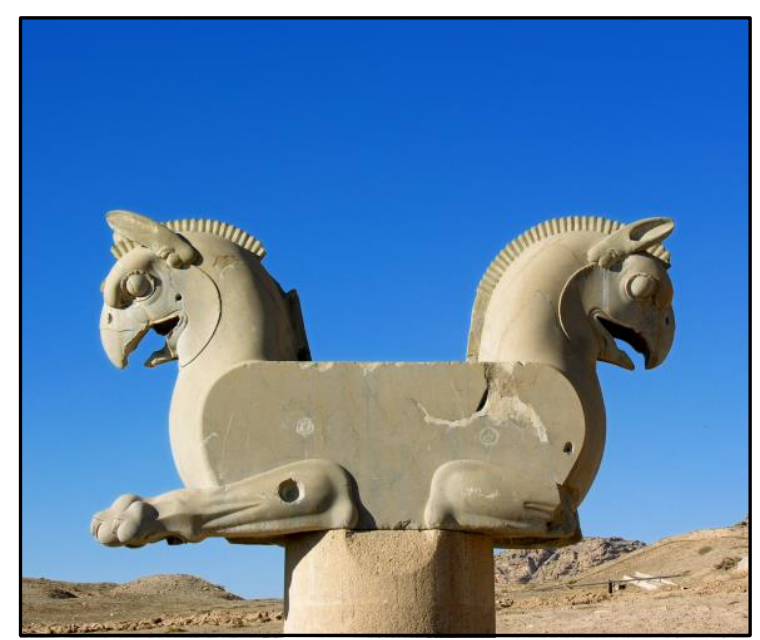

Picture 11: Huma Bird at Takht-e Jamshid

\section{The Logo of University of Tehran}

The logo of University of Tehran was designed by Mohsen Moghadam which was also inspired by Iranian culture and history. University of Tehran's logo was designed from an embossed plaster plate of Sassanid period which was found at Tizfun. As it is shown in Pictures 10 and 11, the two wings design (eagle wings) which is representative of the culture of this period, was used on this plaster work, together with other seals and embossed embroideries. Decorative postscript consisting of small circles, used in period of Achaemenid especially on coins as a decorative element, also used in Sassanid period on coins, signatures and reliefs. (Picture 12, 13). 


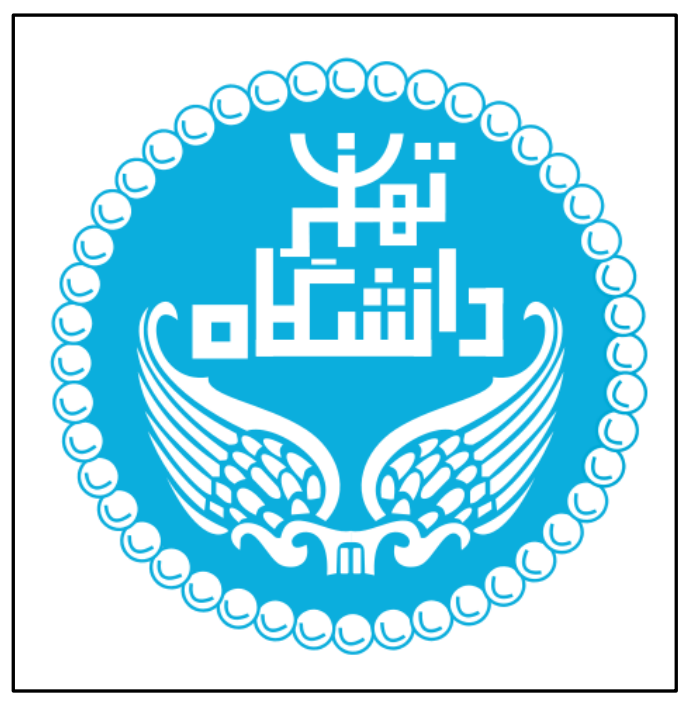

Picture 12: The Logo of Tehran University

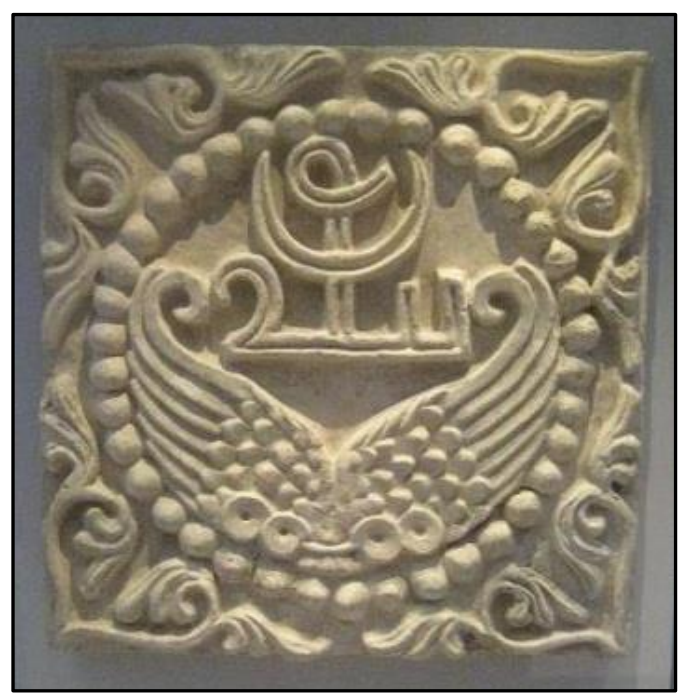

Picture 13: plaster plate found at Tizfun

\section{The Logo of Pasargad Bank}

This logo was designed in 2005 with an inspiration from a metallic wineglass with shape of an animal, found in Achaemenid period. The lion headed wineglass had been made around $5 \mathrm{BC}$ from gold plated bronze. Back in Achaemenid era, most of the cups were designed with shape of animal head, like lion, tiger, and deer. In the past Iranians used to believe that they could transfer animals' power to their own body by drinking in these cups. This logo is an evidence of a historical memory, created by inspiration from the history and culture of Iran (Picture 14, 15). 


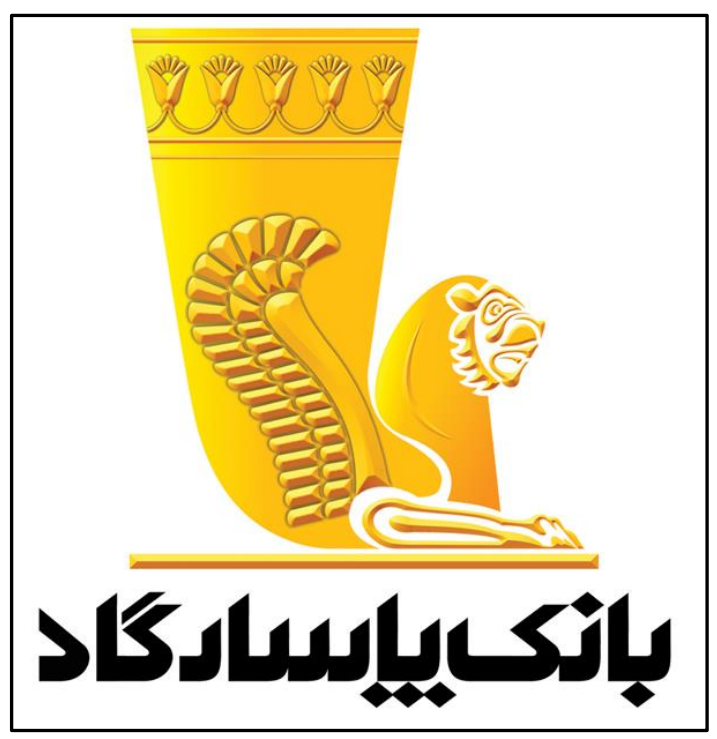

Picture 14: The Logo of Pasargad Bank

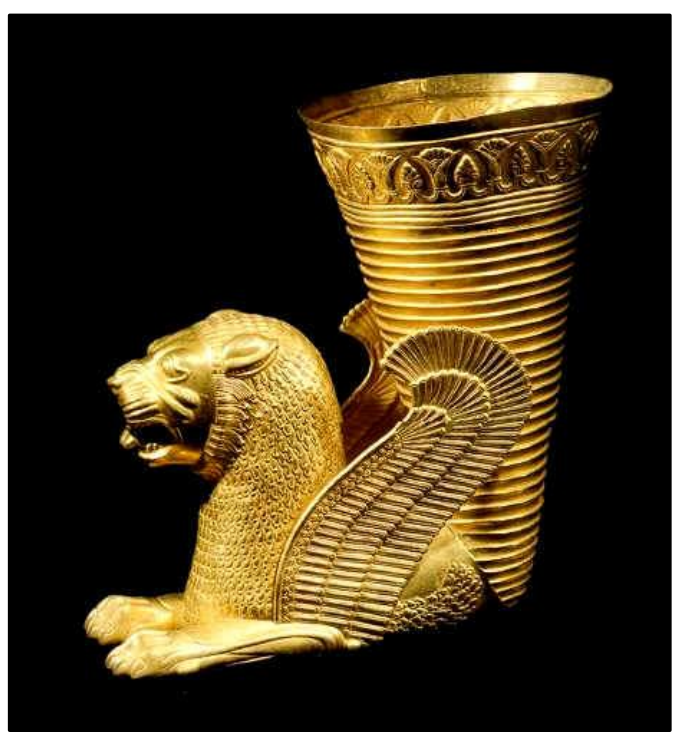

Picture 15: Wineglass form Achaemenid period

\section{The Logo of Persian Bank}

This logo was inspired in 2002 from water lily, which is frequently used on wall artworks in Achaemenid period. Water lily is used as a symbol of peace, life, religion, purity and purgation in almost all carvings of Tact-e Jamshid and known as symbol of Achaemenid Civilization. This flower is used in most decorations as a symbol of peace and friendship in the hands of kings and elders. This flower represents the Iranians as peaceful and merciful nation (Picture 16, 17).

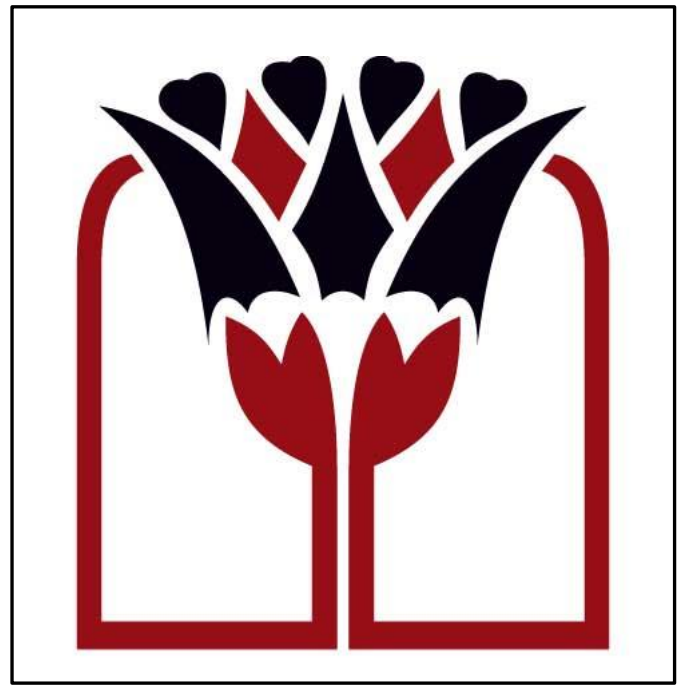

Picture 16: The Logo of Persian Bank.

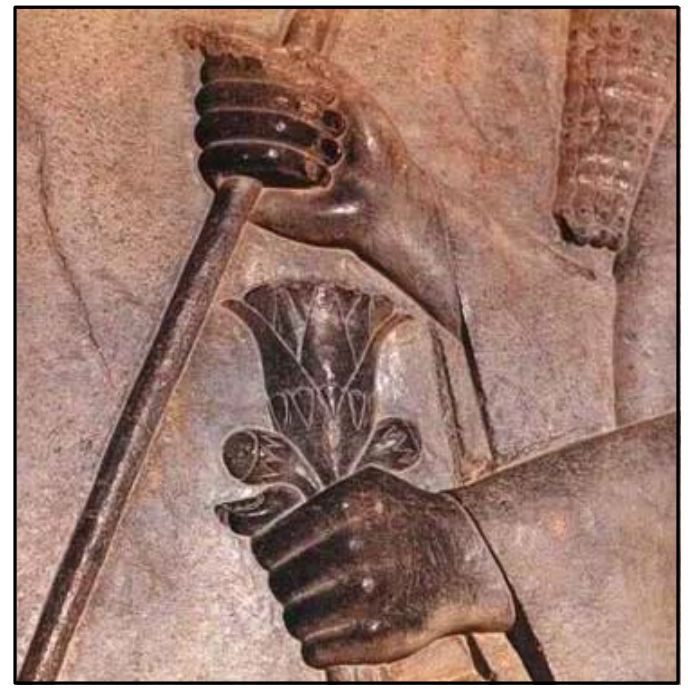

Picture 17: Water lily used in by Achaemenid. 


\section{The Logo of Persepolis Football Club}

This logo was designated in 2004 by an inspiration from the head of double headed cow column at Apadana place in Shush. After the Cyrus the Great, Dariush the Great ruled Persia and Dariush chose the city of Shush as the capital. During his kingdom, several valuable historical monuments were made. Persepolis Football Club used this valuable and important monument at the Apadana place to design its logo. A few modifications were added to this design to better represent a sport club (Picture 18, 19).

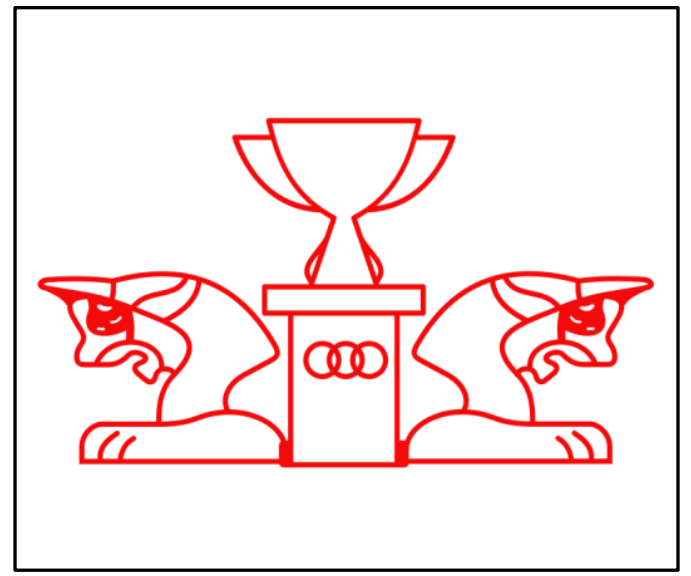

Picture 18: The Logo of Persepolis Football Club

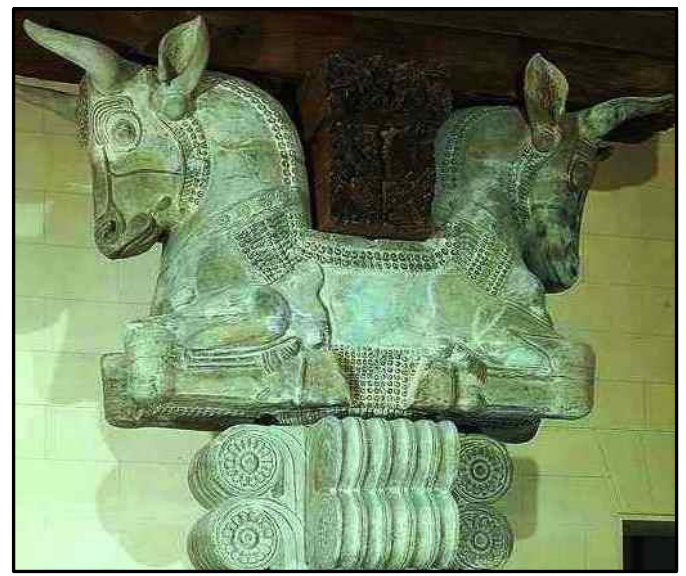

Picture 19: Column head at Apadana palace

\section{The Logo of Pars Oil Company}

The designer of this logo - designed 50 years ago - was inspired by Tact-e Jamshid's embroideries and images in the form of male-headed, sitting lions with wings. Pars Oil Company by using this logo tries to symbolize the intelligence with vigilance, rising, obedience from laws, contemplation, mind, motion, agility and tirelessness with the combination of the lion and its strong hands, flying wings, head and male hat, in a single body (Picture 20, 21). 


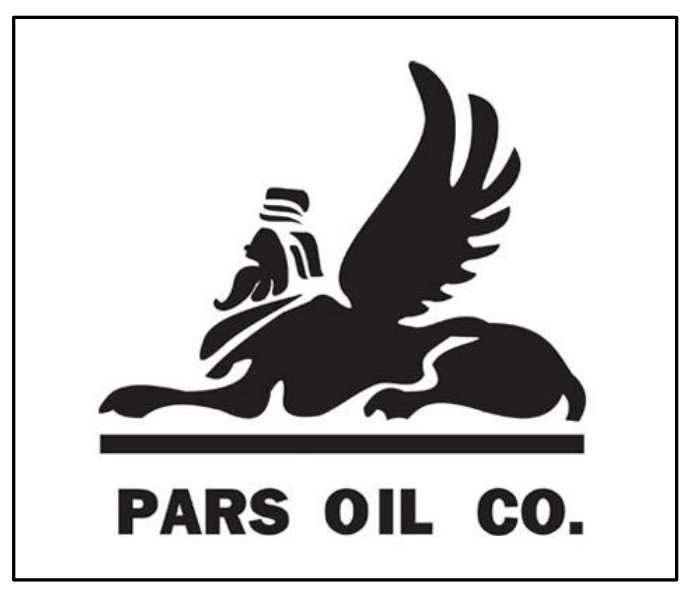

Picture 20: The Logo of Pars Oil Company

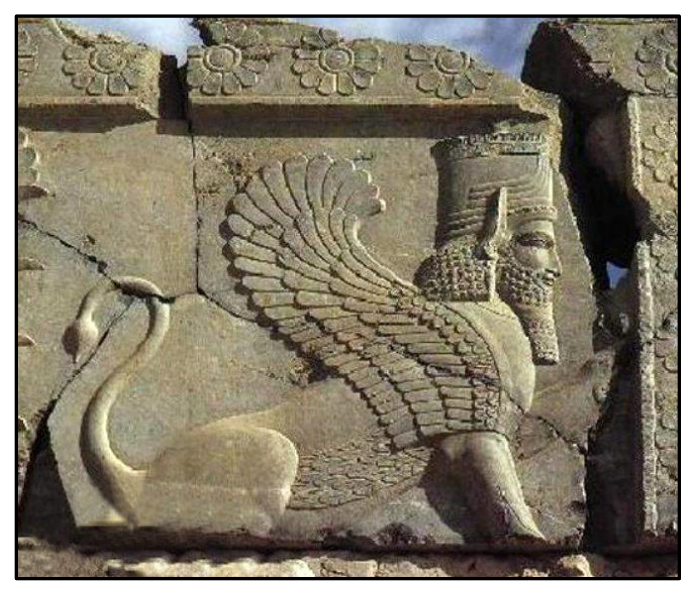

Picture 21: Relief Embroidery of Takht-e

Jamshid

\section{Conclusion}

Iranian civilization has progressed in cultural and artistic aspects during different periods of history. The art has been developed in several periods of history based on several factors. The causes of these effects, investigation of thier impact and having knowledge about the history of graphic art have great importance enabling the artists to produce future works with an inspiration of the historical artifacts. In this article, the historical processes of Iranian graphic art throughout the history was explained by taking the development of Iranian graphic art into consideration in terms of socio-cultural perspective. The effects of religion, belief, sense, politics, culture, historical events, legends and mythology are clearly seen in the analysis of the excavated artefacts. Although some signs of foreign arts were found, these western arts helped to produce special designs by combining embroideries of Iranian culture. Influence of the art in the daily lives of the Iranians is important evidence in explaining Iran's deep and rich culture's importance and dignity. Motifs used in the Iranian daily life inspired from ancient art and cultures are evidences of this fact. Although a number of logos were initially designed long time ago, they have been remained untouched. This is mainly because those logos are "original" and are inspired by Iranian culture. This proves the fact that the history and culture 
of past has a significant effect on Iran's modern graphic art and it is being used in contemporary designs.

\section{References}

Goshayesh, F. (1999). History of Iran and World Art. Tehran: Efaf Publishing House.

Jafari, M. T. (1999). Beauty and Art in terms of Islam. Tehran: Allameh Jafari Publishing House.

Ahmadi Baghbadrani, S. (2009) Art and Religion. Monthly Art Book, 133, 24-28.

Dabiri, A. (2005). Lithography and the Reasons for Spreading in Iran. Magazine Book, 62, 59-66.

Hoseini, Sh. (2012). Iran Graphic before Revolution (1956-1978). Monthly Art Book, 169, 5865.

Jabari Rad, H. (2008). The First Schools of Art in Iran. Art Magazine, 12, 40-49.

Katuziyan, M. A. H. (2010). Creatures of We Iranians. Mehrnameh, 2, 45-46.

Molaei Nia, R. (2008). Introduction of Modern and Contemporary Graphic Factors. Negareh Magazine, 7, 51-63.

Momayez, M. (1996). Regeneration in Iran Art. Speech Magazine, 10, 31-40.

Pirhushyar, S., Marasi, M. (2012). The Position of Iranian Art in Four Distinguished Book of World Art History. Monthly Art Book, 172, 36-43.

Summarized History of Graphic and Poster in Iran (1982, 8 May1s). Cihat, 31, 42-44.

Ebrahimi, F., (2009). Tact-e Jamshid the most symbolic icon of Norouz ceremony, Retrieved at January 18, 2014 from: http://iranshahr.org/

Hoseinpur Hajar, A., (2010). Matching Iranian logos and symbols of ancient Iranian art, Retrieved at March 8, 2014 from: http://persiangfx.com/

Keramati Moghadam, M., (2013).The first human drawings, Retrieved at March 19, 2014 from: http://avalinnaghashi.blog.ir/ 
Kooroshli, A., (2011). History of graphic art in Iran, Retrieved at February 6, 2014 from: http://alikooroshli2.persianblog.ir/

Raeeka, (2011). Man praying, Retrieved at May 2, 2015 from: https://raeeka.wordpress.com/

Rafat, A., (2013). The 30 Best-Looking Airlines Logos in The World, Retrieved at April 12, 2014 from: http://skift.com/2013/10/23/the-30-best-looking-airlines-logos-in-the-world/

Report Informatics Center of Tehran University, (2005). History of Tehran University, Retrieved at January 14, 2014 from: https://puyeshga.ipower.com/ES.ETC/history-ofTehran-University.htm

Sadeghi, M., (2006). The third annual book of students' graphic (Neshaneh): Fredrik Talberg, Retrieved at March 12, 2014 from: http://www.rasm.ir/

Zeka, Y. (2008). Arts \& Humanities Journal: Mirza Abul Hassan Sani ol-Molk Ghaffari, the founder of the first school of painting in Iran, Retrieved at February 18, 2014 from: http://www.noormags.com/ 